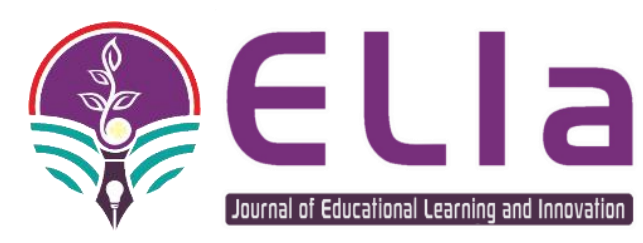

Journal of

Educational Learning and Innovation

p-ISSN:2775-2623 and e-ISSN: 2775-2739

Volume 1 Number 1 Maret 2021, Halaman 33-42

DOI: 10.46229/elia.v1i1

\title{
TANTANGAN GURU DALAM MENGAJAR SATU WAKTU DI SIDH
}

\author{
Sukriyah Barokah ${ }^{1}$, Mega Yuni Ariyanti ${ }^{2}$, Eka Prasetyawati ${ }^{3}$, M. Aulia Fatah ${ }^{4}$, \\ Ulfatun Nafi $\mathbf{a h}^{5}$, Husni Mubarok ${ }^{6}$ \\ 1,2,3,4,5,6 Program Studi Pendidikan Guru Madrasah Ibtidaiyyah (PGMI), Institut Agama \\ Islam Negeri Kudus, Kudus, Indonesia \\ Email: Sukriyahbarokah12@gmail.com ${ }^{1}$, megaariyanti60@ gmail.com ${ }^{2}$, \\ prasetiyawati98@gmail.com ${ }^{3}$, Masfatah5@ gmail.com ${ }^{4}$, uulfa236@gmail.com ${ }^{5}$, \\ husnimubarok@iainkudus.ac.id ${ }^{6}$
}

(Received: 28 Desember 2020; Reviewed: 04 February-2021; Accepted: 06 February-2021; Available online: Maret-2021; Published: Maret-2021)

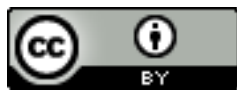

This is an open access article distributed under the Creative Commons

Attribution License

Attribution 4.0 International (CC BY 4.0) (https://creativecommons.org/licenses/by/4.0/ ).

\begin{abstract}
ARTIKEL INFO
Kata Kunci:

Tantangan Guru;

Pembelajaran Jarak

Jauh (PJJ); SIDH;
\end{abstract}

\begin{abstract}
Abstrak. Diedarkannya suatu kebijakan dari pemerintah mengenai pembelajaran daring maka guru di tuntut untuk lebih bersikap kreatif dalam menggunakan media pembelajaran sebagai sarana penunjang pembelajaran di masa sekarang ini agar tercipta pembelajaran yang tidak membosankan bagi peserta didik di masa Covid-19. Mengingat strategisnya peran guru dalam pendidikan, apalagi di era global ini, maka kebutuhan akan guru yang berkualitas menjadi sebuah keniscayaan demi masa depan bangsa yang gemilang. Kebutuhan akan guru yang berkualitas yang semakin tinggi saat ini harus disikapi secara positif oleh para pengelola pendidikan guru. Respons positif ini harus ditunjukkan dengan senantiasa meningkatkan mutu program pendidikan yang ditawarkannya. Perbaikan mutu pendidikan pada jenjang pendidikan tinggi ini jelas akan membawa dampak positif bagi penciptaan guru yang berkualitas kelak di kemudian hari. Metode yang digunakan dalam penelitian ini termasuk dalam metode library research dengan pendekatan kualitatif. Di dalam metode penelitian ini ada empat tahap yaitu; pengumpulan data, pertanyaan peneliti, penyajian data, dan kesimpulan. Dapat disimpulkan, semua pembelajaran yang ada di Belanda dilakukan secara daring, adapun yang dilakukan secara offline hanya $20 \%$ dan sifatnya tutorial yang sifatnya lebih kreatif. Terdapat 21 murid yang mencakup SD, SMP, dan SMA. Jumlah gurunya ada 16 ditambah 1 kepsek berarti 17 guru. Untuk program PJJ bagi mahasiswa yang tinggalnya di luar belanda jumlahnya yaitu 140. SD Reguler di SIDH memiliki semua jenjang dari kelas 1 - kelas 6 tetapi satu jenjang bisa jadi 1 siswa atau paling banyak 3-4 siswa. Kurikulum di SIDH menggunakan K13, untuk memudahkan menggunakan buku BSE.
\end{abstract}

Abstract. With the issuance of a government policy regarding online learning, teachers are required to be more creative in using learning media as a means of supporting learning today so that learning is not boring for students during the Covid-19 era. Given the strategic role of teachers in education, especially 
in this global era, the need for quality teachers is a necessity for the sake of a glorious nation's future. The need for high quality teachers today must be responded positively by teacher education managers. This positive response must be demonstrated by continuously improving the quality of the education programs it offers. Improving the quality of education at the higher education level will clearly have a positive impact on the creation of quality teachers in the future. The method used in this research is included in the library research method with a qualitative approach. In this research method, there are four stages, namely; data collection, researcher questions, data presentation, and conclusions. It can be concluded that all learning in the Netherlands is done online, only $20 \%$ of what is done offline and tutorials are more creative in nature. There are 21 students covering SD, SMP and SMA. There are 16 teachers plus 1 principal means 17 teachers. The PJJ program for students living outside the Netherlands is 140. SD Regular at SIDH has all levels from grade 1 to grade 6 but one level can be 1 student or 3-4 students at most. The curriculum at SIDH uses K13, to make it easier to use the BSE book.

\section{PENDAHULUAN}

Merebaknya virus covid-19 atau yang disebut dengan corona virus diseases 19 atau MERS-Cov yang muncul secara tiba-tiba di seluruh dunia. Virus ini muncul dan mewabah pada Negara tiongkok china lebih tepatnya di kota Wuhan provinsi hubai. Virus covid 19 merupakan sebuah virus yang menyerang paru-paru, dengan gejala awal mengalami batuk, daham, tenggorokan terasa sakit selama berhari-hari dan mengalami sesak nafas. Masa inkubasinya kurang lebih dari 5-6 hari dan paling lama 14 hari. Negara Indonesia khususnya, juga terdampat virus covid-19 ini dan berdampak sangat besar bagi semua hal, salah satunya pendidikan.

Hal yang terjadi sekarang ini dirasa sangat berat bagi pendidik maupun peserta didik. Dengan di edarkan nya surat dari Menteri Pendidikan dan Kebudayaan Republik Indonesia Nomor 04 Tahun 2020 mengenai pelaksanaan kebijakan pendidikan dalam masa darurat penyebaran covid-19 yang dijelaskan bahwasan nya proses belajar-mengajar dilaksanakan dirumah dengan melalui pembelajaran daring atau pembelajaran jarak jauh sebagai upaya memutus mata rantai penyebaran atau penularan Covid19. pemerintah mengenai pembelajaran daring maka guru di tuntut untuk lebih bersikap kreatif dalam menggunakan media pembelajaran sebagai sarana penunjang pembelajaran di masa sekarang ini agar tercipta pembelajaran yang tidak membosankan bagi peserta didik di masa Covid-19.

Media adalah salah satu faktor penentu keberhasilan pembelajaran. Melalui media proses pembelajaran bisa lebih menarik dan menyenangkan, misalnya siswa yang memiliki keterkaitan terhadap warna maka dapat diberikan media dengan warna yang menarik. Begitu juga halnya siswa yang senang berkreasi selalu ingin menciptakan bentuk atau obje yang di inginkan nya, siswa tersebut dapat diberikan media yang sesuai, seperti plastisin, media balok bangun ruang, atau diberiak media gambar lengkap dengan cat nya. Dengan menggunakan media teknologi seperti halnya computer, akan memudahkan siswa dalam belajar, seperti belajar berhitung, membaca dan memperkaya pengetahuan. Program permainan (games) pada komputer banyak yang berisi tentang pembelajaran yang dikemas sangat menyenangkan buat siswa, sehingga siswa seolah tidak merasa sedang belajar.

Pendidikan adalah investasi sumber daya manusia (SDM) jangka 
panjang yang mempunyai nilai strategis bagi kelangsungan peradaban manusia di dunia. Salah satu komponen penting dalaml pendidikan adalah guru. Guru dalam konteks pendidikan mempunyai peranan yang besar dan strategis. Hal ini disebabkan karena guru yang berada di barisan terdepan dalam pelaksanaan pendidikan. Guru yang langsung berhadapan dengan peserta didik untuk mentransfer ilmu pengetahuan dan teknologi, sekaligus mendidik dengan nilai-nilai positif melalui bimbingan dan keteladanan. Guru adalah praktisi pendidikan yang sesungguhnya.

Mengingat strategisnya peran guru dalam pendidikan, apalagi di era global ini, maka kebutuhan akan guru yang berkualitas menjadi sebuah keniscayaan demi masa depan bangsa yang gemilang. Kebutuhan akan guru yang berkualitas yang semakin tinggi saat ini harus disikapi secara positif oleh para pengelola pendidikan guru. Respons positif ini harus ditunjukkan dengan senantiasa meningkatkan mutu program pendidikan yang ditawarkannya. Perbaikan mutu pendidikan pada jenjang pendidikan tinggi ini jelas akan membawa dampak positif bagi penciptaan guru yang berkualitas kelak di kemudian hari.

\section{METODE}

Metode yang digunakan dalam penelitian ini termasuk dalam metode library research dengan pendekatan kualitatif. Jenis penelitian ini mampu menangkap berbagai informasi kualitatif deskripsi teliti, data yang dikumpulkan berwujud kata-kata dalam kalimat atau gambar yang mempunyai arti lebih dari sekedar pernyataan (Sutopo, 2002). Menurut (Mukhtar, 2013), metode deskriptif kualitatif adalah sebuah metode yang digunakan peneliti untuk menemukan pengetahuan dan teori terhadap suatu penelitian pada satu waktu tertentu. Adapun analisis isi merupakan penelitian yang menggabungkan hasil banyaknya penelitian. Di dalam metode penelitian ini ada empat tahap yaitu; pengumpulan data, pertanyaan peneliti, penyajian data, dan kesimpulan. Berdasarkan teknik pengumpulan data dalam metode penelitian ini berupa; teknik pengumpulan data yang berupa dokumentasi yaitu seperti, mencari data mengenai buku, catatan, jurnal, makalah atau artikel dan lain sebagainya (Arikunto S, 2010). Dokumen yang dikumpulkan untuk digunakan dalam pengumpulan data berupa dokumen buku pedoman kurikulum di SIDH, catatn pembelajaran yang dilakukan guru saat mengajar, serta artikel atau referensi lainnya mengenai pendidikan, pembelajaran jarak jauh.

Istilah penelitian kualitatif menurut kirck dan miller pada mulanya bersumber pada pengamatan kualitatif yang di pertentangkan dengan pengamatan kuantitatif. Lalu mereka mendevinisikan bahwa metodologi kualitatif adalah tradisi tertentu dalam ilmu pengetahuan sosial yang secara fundamental bergantung pada pengamatan pada manusia dalam khasnya sindiri dan berhubungan dengan orangorang tersebut dalam bahasanya dan dalam peristilahannya. Penelitian kualitatif memiliki ciri atau karakteristik yang membedakan dengan penelitan jenis lainnya.

\section{HASIL DAN PEMBAHASAN}

\section{A. Tantangan Guru dalam Mengajar Satu Waktu di SIDH}

\section{Pembelajaran di SIDH Pada Jenjang SD}

Dalam penyelengaraan kegiatan belajar mengajar di SIDH, guru yang mengajar hanya ada 2 pada jenjang SD, dan pada jenjang SD ini dibagi menjadi 2 jenjang, yaitu kelas besar terdiri dari kelas 4, 5 dan 6, dan kelas kecil terdiri dari kelas 1, 2, dan 3. Di SIDH guru mengajar di dalam satu waktu dalam jenjang yang berbeda, jadi jika mengajar di kelas 5 dan 6 , kelas 5 di ajar dan kelas 6 diberi tugas, untuk kurikulum yang digunakan waktu itu kurikulum K-13, buku yang digunakan dari BSE, untuk pjj pembelajarannya menggunakan file yang juga dari BSE, ketika ujian untuk kelas 6 sebenarnya para siswa dari semua negara yang belajar di 
SIDH hadir di SIDH untuk ujian, tapi untuk tahun ini dilaksanakan secara online.

\section{Cara Mengefektifkan Pembelajaran Dalam Satu Waktu di SIDH}

Pembelajaran merupakan kegiatan yang berproses pada setiap jenjang pendidikan. Pembelajaran efektif adalah pembelajran yang menghasilkan. Karena kondisi tersebut, maka guru haru siap menghadapi segala keadaan, tetapi berkat jam terbang guru yang sudah banyak maka dalam mengajar satu waktu dalam 2 kelas sudah bisa diatasi, jadi jika mengajar 2 kelas maka kelas yang satu di ajar, dan kelas yang lain di beri tugas, untuk kelas besar selama ini sudah mandiri jadi di kasih bahan terus mengerjakan tugas sendiri, jadi guru tersebut bisa mengajar di kelas lain, berbeda jika mengajar di dua kelas sekaligus, mengajar di tiga kelas sekaligus lebih sulit karena kondisi siswa yang berbeda-beda, maka campur tangan orang tua sangat penting untuk menjelaskan lagi materi di sekolah.

\section{B. Pembelajaran Jarak Jauh}

Penyebaran akibat dampak Covid19 ini memberikan pengaruh yang sangat besar bagi pendidikan di Indonesia maupun di seluruh dunia. Proses pembelajaran dilakukan dengan model pembelajaran Jarak Jauh atau disebut dengan PJJ. Pembelajaran Jarak jauh merupakan proses pemelajaan yang dilakukan tidak dalam bentuk tatap muka secara langsung antara pendidik (guru) dan Peserta didik (siswa). Keduanya tidak dilaksanakan berada ditempat yang sama pada saat pembelajaran berlangsung, melainkan dikaksanakan di rumah masingmasing.

Untuk PJJ (Pembelajaran Jarak Jauh) SD dimulai dari tahun 2008 dengan dimulai dengan hanya 3 anak dan sekarang sudah 100 lebih bahkan hampir 120 an siswa, untuk PJJ pada semester lalu disesuaikan dengan standar penyelenggaran jarak jauh dari dinas, untuk guru PJJ karena guru kelas regular sudah mengajar kelas regular hingga sore, maka untuk guru PJJ SIDH merekrut penduduk sekitar serta mahasiswa untuk menjadi guru PJJ dengan melalui syarat yang sudah ditentukan, untuk pembelajaran PJJ untuk sekarang sudah waktunya sudah tidak terlalu lama, karena para siswa sudah bersekolah di sekolah lokal, jadi guru hanya membuka pembelajaran untuk apa yang akan dipelajari hari ini.

\section{Kurikulum di SIDH}

\section{Pengertian Kurikulum}

Menurut (Kerr, J. F, 1962) Kurikulum merupakan pembelajaran yang dirancang dan dilakukan oleh individu maupun kelompok berdasarkan di luar kelas maupun di dalam kelas. Adapun Menurut UU. NO. 20 Tahun 2003: merupakan seperangkat rencana dan pengaturan mengenai tujuan isi dan bahan pengajaran serta cara yang digunakan sebagai pedoman penyelenggaraan kegiatan pembelajaran untuk mencapai tujuan pembelajaran.

Menurut Hollis, Caswell dan Doak S. Campbell memandang kurikulum bukan sebagai sekumpulan mata pelajaran, akan tetapi kurikulum merupakan semua pengalaman yang diharapkan dan dimiliki peserta didik dibawah bimbingan seorang pendidik atau guru.

Dapat diketahui untuk kurikulum menggunakan kurikulum K-13, baik itu untuk PJJ maupun regular, di SIDH buku yang digunakan sama untuk kelas regular dan PJJ yaitu BSE, hanya yang membedakan bobot nya saja untuk pjj yang waktu belajar nya di persempit, karena selain keterbatasan waktu juga karena sebagian besar siswa sudah belajar di sekolah lokal, maka dengan hal ini diperlukan bimbingan orang tua untuk membimbing anaknya, untuk kelas regular sama seperti di Indonesia. Kemudian pada 20 juli 2020 SIDH sudah kembali dibuka.

\section{Konsep Kurikulum 2013}

Kurikulum adalah program yang dibuat oleh pemerintah yang di tujukan kepada peserta didik yang didalamnya memuat metode pembelajaran, evaluasi, program Pendidikan, perubahan pengajaran, supervise, bimbingan 
konseling, administrasi dan hal-hal yang menyangkut struktural.

Pendidikan di Indonesia mengalami beberapa kali perubahan kurikulum diantaranya KTSP, Kurikulum 2013, dan Kurikulum 2013 edisi revisi. Kurikulum 2013 yaitu usaha yang dilakukan oleh pemerintah sebagai bagian dari proses pengembangan dan perpaduan dari kurikulum sebelumnya yaitu kurikulum berbasis kompetensi (2014), Kurikulum Tingkat Satuan Pendidikan (2006), serta Kurikulum tingkat satuan pendidikan berbasis karakter (2010). Sehingga kurikulum 2013 dinamakan dengan kurikulum 2013 berbasis kompetensi dan karakter. Tujuan dari kurikulum 2013 ini adalah meningkatkan mutu proses dan hasil pendidikan yang mengarah pada pembentukan karakteristik peserta didik sesuai dengan standar kompetensi lulusan pada setiap satuan pendidikan. Pendidikan karakter menekankan pada keteladanan, penciptaan lingkungan, dan pembiasaan melalui berbagai tugas keilmuan dan kegiatan yang kondusif.

\section{Penerapan Kurikulum 2013 Pada SIDH}

Kurikulum memiliki peranan yang sangat penting dalam satuan pendidikan. Karena, kurikulum sebagai acuan dalam pelaksanaan suatu pendidikan. Begitupun dengan Sekolah Indonesia Dden Haag (Belanda) ini. Sekolah Indonesia Den Haag (Belanda) menerapkan kurikulum sepenuhya sesuai dengan standar kurikulum nasional yang ada di Indonesia, yaitu kurikulum 2013. Penerapan kurikulum 2013 ini telah ditetapkan oleh Badan Nasional Standar Pendidikan (BNSP) Jakarta untuk menggantikan KTSP (Kurikulum Tingkat Satuan Pendidikan) pada tahun 2006.

Penerapan kurikulum pembelajaran pada Sekolah Indonesia Den Haag (Belanda) seperti halnya sekolah-sekolah yang berada di Indonesia. Materi pembelajaran yang diajarkan juga seperti halnya sekolah di Indonesia, yaitu materi yang didapat dari buku keluaran pemerintah yaitu buku tematik (tema). Namun bedanya dengan sekolah di
Indonesia yaitu, untuk buku di sekolah Indonesia diedarkan dalam bentuk cetak sedangkan pada Sekolah Indonesia Den Haag (Belanda) diberikan berupa file. Dalam pembelajaran guru memberikan kiriman file buku kepada peseta didik sesuai dengan tema yang akan dipelajari. Kemudian, setelah memberikan file buku pembelajaran guru baru menjelaskan materi tersebut.

Sistem pembelajaran tatap muka ataupun tidak, untuk di Sekolah Indonesia Den Haag (Belanda) menggunakan dua sistem pembelajaran, yaitu secara tatap muka dan secara jarak jauh. Untuk pembelajaran yang jarak jauh ini diperuntukkan bagi anak-anak yang rumahnya sangat jauh dari sekolah. Namun, untuk nanti pada saat ujian dilakukan secara langsung bertatap muka.

Perangkat pembelajaran di Sekolah Indonesia Den Haag (Belanda) juga sama seperti perangkat pembelajaran sekolah di Indonesia, yang terdiri dari Silabus, RPP (Rencana Pelaksanaan Pembelajaran), Bahan Ajar, Prota, dan Promes.

Dalam mengajar di Sekolah Indonesia Den Haag (Belanda) juga memiliki tantangan ketika menerapkan kurikulum 2013 yaitu karena peserta didik dan guru tinggal di Belanda maka tantangan yang ditekankan yaitu mengenai nilai-nilai nasionalisme dan karakter keagamaan. Penerapan nila-nilai nasionalisme ini peserta didik diajak untuk selalu mengingat tanah air Indonesia dengan selalu memperingati kemerdekaan Indonesia, dan lain sebagainya. Kemudian, mengenai nilai keagamaan, karena mayoritas agama disana non muslim maka cara yang dapat dilakukan dengan menanamkan kepercayaan peserta didik yaitu selalu mengingatkan untuk melakukan ibadah untuk selalu mendekat kepada Allah, bershodaqoh atau berbagai sesama dengan orang lain walaupun orang lain tersebut non muslim.

Setelah perancangan kurikulum yaitu kurikulum terbaru 2013 selanjutnya adalah pengimplementasian kurikulum 2013. Dalam pengimplementasikan 
kurikulum 2013, ada faktor-faktor yang perlu dirperhatikan yaitu:

1. Faktor Kurikulum

Kurikulum sangat berpengaruh pada proses pengimplementasian kurikulum. Faktor yang harus ada dalam kurikulum adalah kejelasan tujuan, pendekatan, serta tata Kelola dan kurikulum haruslah realistis dan relevan sehingga dapat mensukseskan proses imolementasi. Kurikulum yang realistis dan relavan akan memberikan ruang kepada guru intuk mengembangkan bahan ajar yang sesuai dengan kehidupan serta lingkungan peserta didik. dan bahan ajar juga harus memperhatikan psikologis anak.

2. Faktor Guru

Peran guru sangat penting dalam pengimplementasian kurikulum. Seorang guru harus memiliki kompetensi professional, pedagogic dan kompetensi keterampilan maupun kepribadiann dan social sehingga nantinya guru akan membuat pengimplementsian kurikulum ini menjadi sukses dan sesuai tujuannya.

3. Faktor Sarana dan Prasarana

Sarana dan prasarana menjadi poin penting dalam pengimplementasian kurikulum. Sarana dan prasarana dalam pemgimplementasian kurikulum yaitu bahan ajar, peralatan dan bahan laboratorium, ketersediaan media pembelajaran, aksesibility, serta pemeliharaan, perawatan dan pengembangan sarana dan prasarana.

4. Faktor Iklim dan Budaya Sekolah

Guru merupakan kandidat yang menciptakan budaya dan iklim sekolahyang kondusif. Peran ini bisa melalui sikap, perilaku dan kebiasaan guru dalam kegiatankegiatan di sekolah. Iklim dan budaya bisa dilaksanakan pada proses belajar-mengajar. Dalam hal ini bisa dimulai dengan melakukan Langkah-langkah ilmiah yaitu mengamati, menanya, mencoba, menganalisis, mengkontruksi serta menarik kesimpulan.

5. Faktor Peran Kepala Sekolah

Seorang kepala sekolah memiliki peran sebagai menegement implementasi kurikulum. Peran itu meliputi perencanaan, pelaksanaan, pemonotoring, pengevaluasi dan pengembang. Seorang kepala sekolah harus mampu menotivasi dan mendorong guru serta staf yang bersinggungan dengan proses pengemplentasian kurikulum.

4. Dampak Penerapan Kurikulum 2013 di Sekolah Indonesia Den Haag (SIDH)

Indonesia telah mengalami perubahan kurikulum beberapa kali. Perubahan kurikulum terakhir dari Kurikulum Tingkat Satuan Pendidikan (KTSP) ke Kurikulum 2013 yang sangat berdampak pada peserta didik di Sekolah Indonesia Den Haag dan Sekolah Indonesia Kuala Lumpur, yaitu:

a. Peserta didik memiliki sikap spiritual. Dimana peserta didik yang beragama Islam terlihat sudah rajin beribadah.

b. Peserta didik memiliki karakter yang sesuai dengan kurikulum 2013 di Indonesia. Diantaranya bersikap jujur, disiplin, bertanggung jawab, dan lain sebagainya.

c. Pada kurikulum 2013 ini lebih banyak peserta didik melakukan praktik secara langsung dalam proses pembelajaran yang menekankan pada sebuah keterampilan.

\section{Metode Pembelajaran di SIDH}

Menurut (Prawiradilaga, 2007) metode pembelajaran merupakan prosedur atau langkah-langkah atau cara yang digunakan oleh guru dalam mencapai tujuan pembelajaran.

Metode pembelajaran harus disesuaikan dengan karakteristik materi yang akan disampaikan kepada peserta 
didik agar tercapai suatu tujuan pembelajaran yang efektif.

Setiap jenjang punya tantangan masing-masing, karena kondisi yang berbeda, jadi para guru harus siap untuk selalu beradaptasi, dan juga tidak ada metode khusus yang digunakan, dan juga dengan adanya jam terbang yang tinggi dari para guru sehingga bisa menghadapi kondisi ini, dan juga bantuan dari orang tua dalam membantu pemahaman anak sangat dibutuhkan karena pembelajaran dengan guru yang kurang mendalam.

Sarana prasaran di SIDH sangat jauh berbeda dibanding Indonesia. Di SIDH unggulanyya pada internet. Untuk lab. Masih jauh dari Indonesia, dan masih sangat banyak lagi alat yang digunakan. Siswa berprestasi (tergantung pada siswa dan guru hanya membimbing). Di SIDH lomba-lomba tidak ada, fokus guru hanya memberi bimbingan pada siswa.

Prasarana terbatas di SIDH. Ketika kekurangan ruang belajar maka di Belanda harus meminta izin terlebih dahulu guna untuk menambah bangunan, disana sangat ketat sudah ada aturannya. Sehingga tidak mungkin untuk menambahkan ruang kelas atau ruang bangunan. Bantuan dari pemerintahan dari dana BOS. Kendala terbesar yaitu masalah tersebut prasarana gedung SIDH dibawah kementerian luar negeri. Untuk perawatanya harus ditraining diawasi.

Bergantian ketika sedang belajar dan untuk ekstra dilakukan secara bersamaan. Untuk kesehariannya sekolah di SIDH tidak memakai seragam hanya pada hari senin untuk upacara dan ketika mengikuti ekstra pramuka harus menggunakan seragam. Media yang digunakan untuk proses pembelajaran antara lain globe, peta, matematic juga. Untuk karya murid sendiri dipajang dikelas dan terdapat juga sebuah LCD.

\section{E. Dampak Covid 19 Pada Pembelajaran di SIDH}

Virus corona termasuk kategori dalam zonasi (ditularkan antara hewan dan manusia). Covid-19 sudah menjadi masalah kesehatan global yang menyebabkan infeksi terhadap saluran pernafasan pada manusia. Penyebaran virus corona itu berdampak pada manusia kurang lebih 2-14 hari. Memicu percepatan transformasi pendidikan pandemi covid-19 yang datang tak di undang menyebabkan penutupan berbagai jenjang pendidikan dalam upaya dalam menghentikan penyebaran virus corona tersebut, kerja sama antara orang tua dan guru selama pandemi peserta didik tentu akan belajar dirumah dengan pengawasan orang tua.

Selama Belanda lockdown, SIDH juga melaksanakan pembelajaran di rumah karena selain mengikuti peraturan di Indonesia SIDH juga mengikuti peraturan di belanda, jadi sejak awal maret tahun ini sudah melaksanakan belajar dari rumah, untuk kesulitan nya, para guru kesulitan jika ada praktek yang berkaitan dengan api karena takut jika terjadi kebakaran jika para anak tidak didampingi orang tua, jadi hal itu tidak tidak lakukan para guru, dalam pembelajaran dirumah ini anak pasti merasa bosan, tapi karena situasi yang terjadi begitu mendadak jadi para guru belum menemukan solusi yang menarik untuk belajar, untuk ujian akhir semester ini dilaksanakan melalui google form, untuk pjj masih seperti biasa.

\section{F. SIDH - Info Umum (Juli - 2020)}

Tabel 1. Status Sekolah di SIDH

Status (ID) Status (NL)

\begin{tabular}{llr}
\hline Sekolah Swasta & Sekolah Asing \\
Berbantuan & (Buitenlandse School)
\end{tabular}

1. Menyelenggarakan pelayanan pendidikan yang berlandaskan nilainilai religius dan budaya indonesia.

2. Menyelenggarakan pendidikan bermutu menggunakan kurikulum indonesia.

3. Menyelenggarakan lulusan yang mampu berkolaborasi dan berkompetisi secara global.

4. Meningkatkan "rate of admittance" lulusan ke perguruan tinggi bermutu di dalam maupun di luar negeri. 
5. Menyediakan sarana dan prasarana pendidikan berstandar internasional.

6. Melaksanakan diplomasi budaya Indonesia.

Tabel 2. Jumlah Siswa di SIDH

\begin{tabular}{lcccc}
\hline Program & \multicolumn{4}{c}{ Jumlah Siswa } \\
& SD & SMP & SMA & Total \\
Reguler & 9 & 3 & 9 & 21 \\
PJJ & 87 & 28 & 27 & 142 \\
& & & & \\
\hline & 96 & 31 & 36 & 163 \\
\hline
\end{tabular}

Tabel 3. Akreditasi SD, SMP, dan SMA

\begin{tabular}{cccc}
\hline No. & Jenjang & $\begin{array}{c}\text { Nilai } \\
\text { Akreditasi }\end{array}$ & $\begin{array}{c}\text { Peringkat } \\
\text { Akreditasi }\end{array}$ \\
\hline 1. & SD & 95 & $\begin{array}{c}\text { A (Amat } \\
\text { Baik) }\end{array}$ \\
2. & SMP & 91 & $\begin{array}{c}\text { A (Amat } \\
\text { Baik) }\end{array}$ \\
3. & SMA & 93 & $\begin{array}{c}\text { A (Amat } \\
\text { Baik) }\end{array}$ \\
\hline
\end{tabular}

\section{SEKOLAH INDONESIA DEN HAAG}

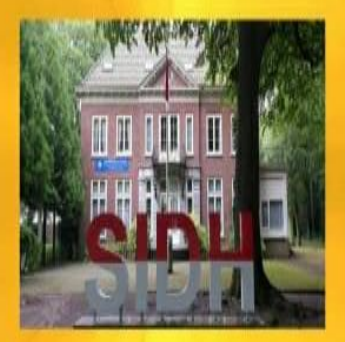

Gambar 1. Profil Sekolah Indonesia Deen Harg (SIDH)

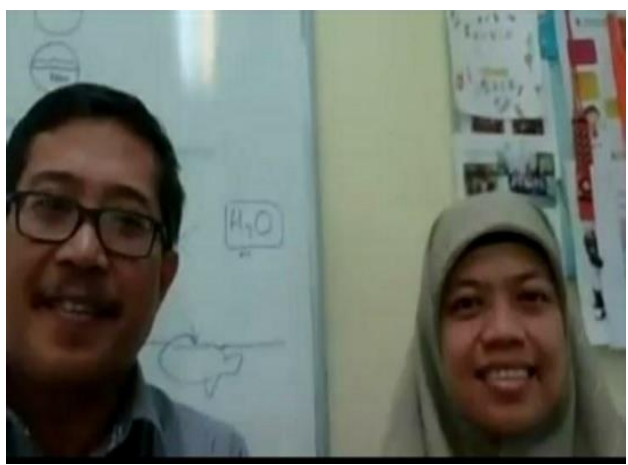

Gambar 2. Guru di SIDH Belanda

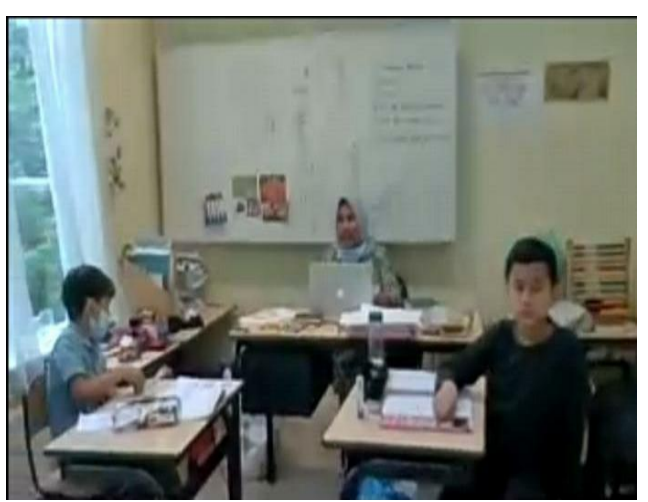

Gambar 3. Pembelajaran satu waktu pada siswa di SIDH

\section{KESIMPULAN}

Berdasarkan penelitian mengenai Tantangan Guru dalam mengajar satu waktu berdasarkan Kurikulum 2013 di Sekolah Indonesia Den Haag (SIDH) Belanda dapat disimpulkan sebagai berikut.

Semua yang ada di belanda dilakukan secara daring, adapun yang dilakukan secara offline hanya 20 persen dan sifatnya tutorial yang sifatnya lebih kreatif. Terdapat 21 murid yang mencakup SD, SMP, dan SMA. Jumlah gurunya ada 16 ditambah 1 kepsek berarti 17 guru. Untuk program PJJ bagi mahasiswa yang tinggalnya di luar belanda jumlahnya yaitu 140. Mereka dituntut untuk belajar di sekolah lokal/ internasional. Kegiatan belajar PJJ dilakukan di sore hari. Kurikulum yang digunakan masih mengikuti program pembelajaran di indonesia karena mereka tinggal di berbagai negara yang berbeda seperti amerika Eropa, dll. Maka disini yang menjadi tantangan yang ditekankan yaitu menanamkan nilai-nilai nasionalisme dan karakter keagamaan yang terpenting. Sekolah Indonesia ini menjadi bagian dari diplomasi budaya karena harus menampilkan berbagai kesenian dan kebudayaan diberbagai event seperti pencak silat, tari-tarian dan lain sebagainya. Untuk SD di bagi 2 kelas besar dan kelas kecil. Kelas 1-3 sendiri di Kelas kecil sedangkan kelas 4-6 sendiri di SD besar dibedakan antara kelas kecil dan besar. Di belanda ini ada beberapa 
kategori sekolah yaitu sekolah lokal dari PAUD sampe SMA. Ada juga sekolah non Belanda. Sejak tahun 2011 sekolah non belanda harus menyesuaikan dibagi menjadi 3 kategori yaitu sekolah Internasional. Sekolah tersebut sama dengan sekolah asing bedanya yaitu badan atau lembaga yang mengakreditasi sekolah tersebut. Sekolah internasional diakreditasi oleh lembaga akreditasi internasional. Jumlah siswa regulernya cuma ada 21 orang. Anak SD berjumlah 9 orang (SD kecil dan besar), SMP 3 orang kelas $2 \mathrm{smp}$ aja, sedangkan SMA ada 9 (3 orang kls 10, 3 orang kelas 11 dan 3 orang kelas 12). Kemudian ada program siswa pendidikan jarak jauh yg berjumlah 142 yang tinggal di berbagai belahan dunia. Slogannya yaitu berbudaya indonesia berstandar internasional. Selama 2016-2021, sebanyak 25 lulusan diterima di perguruan tinggi tanah air 16 lainnya di terima di universitas yang ada di universitas Belanda sendiri, Dapat menerima siswa dari anak anak para diplomat oleh kedutaan yang bersangkutan, tidak bisa menerima siswa lain, Sekolah asing (sekolah yang dibangun dikelola oleh negara lain dalam hal ini (Indonesia) di Belanda menggunakan kurikulum nasional negara tersebut kemudian diakreditasi oleh lembaga akreditasi nasional dalam negara yg bersangkutan. Sedangkan bahasa pengantarnya terdapat 3 pilihan antara Inggris, Jerman, Prancis. Kemudian Di pilih bahasa Inggris sebagai bahasa pengantar). SD Reguler di SIDH memiliki semua jenjang dari kelas 1 - kelas 6 tetapi satu jenjang bisa jadi 1 siswa atau paling banyak 3-4 siswa. Dalam penyelanggaraan KBM, guru itu hanya ada 2 di SD. Secara spesifik ada 3, kebetulan 1 orang hanya bisa hadir dalam satu hari misalnya. Disini kelas dibagi 2, SD besar dan SD kecil. SD kecil itu ada kelas 1, 2, 3, 4 dan SD besar ada kelas 5 dan kelas 6. Mengajarnya dalam satu waktu, misalkan mengajar kelas 5 sementara kelas 6 dikasih tugas, begitupun sebaliknya. Kurikulum di SIDH menggunakan K13, untuk memudahkan menggunakan buku BSE. Tahun ini UN seluruh kelas 6 secara online karena ada wabah pandemi covid 19. Tahun sebelumnya hadir di SIDH untuk melaksanakan ujian. Itulah gambaran SD Reguler. Sedngkan PJJ untuk SD sebetulnya paling lama dan dimulai pada tahun 2008. Mulai dari 3 siswa sampai akhirnya berkembang. Tahun kemarin sekitar sampai 120 untuk PJJ nya saja. Jadi, orang tua cukup antusias untuk menyekolahkan anak- anak di PJJ SD. Kemudian kurikulumnya menggunakan BSE.

Dari kesimpulan diatas, dapat diberikan saran sebagai berikut:

1. Bagi pemerintah yang bertanggung jawab dalam pendidikan dan Tantangan Guru dalam mengajar satu waktu berdasarkan kurikulum 2013 dapat melakukan suatu tindakan dan juga dapat mengatasi suatu permasalahan yang timbul dalam permasalahan tersebut agar ada tingkatan guru pada saat mengajar tidak dalam satu waktu dalam sehari, khususnya sekolah yang berada di luar negeri.

2. Bagi guru sebagai orang yang menggerakkan dan melaksanakan tantangan mengajar dalam satu waktu berdasarkan kurikulum 2013 mampu menerapkan kurikulum 2013 ini dengan semaksimal mungkin sehingga tujuan yang ingin dicapai dapat terwujudkan dengan baik.

3. Bagi peneliti lainnya yang ingin melakukan sebuah penelitian serupa mengenai tantangan mengajar dalam satu waktu berdasarkan kurikulum 2013 di Sekolah Indonesia Den Haag (SIDH) Belanda dapat mengembangkan penelitian ini lebih rinci lagi seperti apa penerapan kurikulum 2013 ini di sekolah tersebut. 


\section{DAFTAR PUSTAKA}

Arikunto, S. 2010. Prosedur Penelitian Suatu Pendekatan Praktik. Jakarta: Rineka Cipta.

Caswell, H.L. \& Campbell, D.S. 1935. Curriculum Development. New York: American Book Company.

Depdiknas. 2003. Undang-undang RI No.20 tahun 2003 tentang sistem pendidikan nasional.

H.B. Sutopo. 2002. Pengantar Penelitian Kualitatif. Surakarta: Universitas Sebelas Maret Press.

Kemendikbud. 2013. Modul Pelatihan Implementasi Kurikulum 2013. Jakarta: Kementerian Pendidikan dan Kebudayaan RI.

Kerr, J.F. (1968). Changing the curriculum. London: University of London Press.

Mukhtar. 2013. Metode Praktis Penelitian Deskriptif Kualitatif. Jakarta Selatan: Referensi (GP Press Group).

PGMI IAIN Kudus. 2020. "Kuliah Lapangan di Belanda-Prodi PGMI." Dikutip dari https://youtu.be/lEF03L4ysmE. Diakses Pada tanggal 13 November 2020.

Prawiradilaga, Dewi Salma. 2007. Prinsip Disain Pembelajaran. Jakarta: Kencana Prenada Media Group.

Prodi BKPI. 2020. "Kuliah Kerja Lapangan di Sekolah Indonesia Kuala Lumpur Malaysia." Dikutip dari

https://youtu.be/bZqI8Hdk0Ec.

Diakses Pada tanggal 14 November 2020.

Sekolah Indonesia Deen Harg. 2020. Wassenar Netherlands. Dikutip dari

https://id.indonesia.nl/kbri/sekolah -indonesia-den-haag. Diakses pada tanggal 21 September 2020.

Surat Edaran Kemendikbud No. 4 Tahun $2020 . \quad$ Pelaksanaan KebijakanPendidikan dalam Masa Darurat Penyebaran Corona Viru Disease Covid 19. dari https://pusdiklat.kemdikbud.go.id/ surat-edaranmendikbud-no-4tahun-2020-tentang-pelaksanaankebijakan-pendidikandalam-masadarurat-penyebaran-corona-virusdisease-covid-1-9/ 